\title{
Prevalence of Hepatitis C Virus Infection among Hemophiliacs in Central Brazil
}

\author{
Adriana P Barbosa, Regina MB Martins $/{ }^{+}$, Sheila A Teles, Simonne A Silva, \\ Jaqueline M Oliveira*, Clara FT Yoshida*
}

Instituto de Patologia Tropical e Saúde Pública, Universidade Federal de Goiás, Caixa Postal 131, 74605-050 Goiânia, GO, Brasil

*Departamento de Virologia, Instituto Oswaldo Cruz-Fiocruz, Rio de Janeiro, RJ, Brasil

In order to investigate the hepatitis $C$ virus $(H C V)$ infection prevalence and risk factors in hemophiliacs in Central Brazil, 90 patients were interviewed and serum samples tested for HCV RNA and anti-HCV antibodies. An overall prevalence of 63.3\% (CI 95\%: 53.0-72.7) was found. Multivariate analysis of risk factors showed that number of blood transfusions was significantly associated with this infection. Most hemophiliacs received locally produced cryoprecipitate. All infected patients were transfused before the screening of blood units for anti-HCV. However, hemophiliacs who received exclusively screened cryoprecipitate were HCV negative. It confirms the expected decline in transfusion-acquired hepatitis $C$.

Key words: hepatitis C - hemophilia - prevalence - Central Brazil

Hepatitis $\mathrm{C}$ virus (HCV) infection is an emerging global public health problem with particular relevance in multiple transfused patients as hemophiliacs. The majority of patients who received clotting factors before the introduction of virus-inactivation methods and screening tests for anti-HCV in blood banks have been infected with HCV. High prevalence rates (39-98\%) of antibodies to HCV (anti-HCV) have been found in hemophiliac populations (Arteaga-Vizcaíno et al. 1993, Troisi et al. 1993, Blanchette et al. 1994, Jackson et al. 1994, Ahmed et al. 1996). In Brazil, and specially in the State of Goiás, coagulation factor replacement therapy in hemophiliacs was basically done with locally produced cryoprecipitate and fresh-frozen plasma. The use of clotting factor concentrates became common only after 1997, more than a decade after the introduction of virus-inactivation techniques. As data concerning HCV infection in Brazilian hemophiliacs are still rare (Rocha et al. 1994, Oliveira et al. 1999, Martins et al. 2000), we sought to assess an overall $\mathrm{HCV}$ prevalence of infection (anti-HCV and RNA-HCV) in hemophiliacs in Central Brazil. In addition, we studied risk factors associated with $\mathrm{HCV}$ infection in this population.

The study population consisted of 90 hemophiliacs, representing $60 \%$ of the hemophiliac population of Goiânia city, Central Brazil (1,000,000 inhabitants). Between February and July 1997, all patients were interviewed for risk factors to $\mathrm{HCV}$ infection. A standardized

This work received financial support from CNPq.

${ }^{+}$Corresponding author. Fax: +55-62-202.3066. E-mail: rbringel@terra.com.br

Received 2 October 2001

Accepted 11 April 2002 form was used to collect data on age, number of previous transfusions, type(s) of blood product received, transfusion before November 1993 (blood not screened for anti$\mathrm{HCV}$ ), tattooing, intravenous drug use, dental treatment, multiple sex partners, sexually transmitted diseases, and possible household contact with hepatitis. Permission for carrying out the study was granted by the Hemophiliac Association of Goiás and informed consent was obtained from all participants. Sera were obtained and stored at $-20^{\circ} \mathrm{C}$ until tested.

The samples were screened by ELISA for the presence of anti-HCV antibodies (INNOTEST HCV Ab III, Innogenetics NV, Belgium). Positive samples were retested for confirmation using a line immunoassay (INNO-LIA HCV Ab III, Innogenetics). All samples were submitted to RNA extraction, reverse transcription, and a nested PCR with primers complementary to the conserved area of the 5' non-coding region of HCV, essentially as describe by Ginabreda et al. (1997). Prevalence and $95 \%$ confidence intervals $(95 \% \mathrm{CI})$ were calculated. Risk factors, estimated by odds ratio in univariate analysis, were in a second step analyzed by multiple logistic regression to identify possible confounders. Statistical significance was assessed at the 0.05 probability level in all analyses. Statistical evaluations were performed using the Epiinfo 6.0 program developed by the Centers for Disease Control and Prevention (Atlanta, GA) and "EGRET" ("Epidemiological, Graphics, Estimation and Testing Package", 1991).

The vast majority of the patients $(96.5 \%)$ had hemophilia A, which was identified as severe, moderate, and mild in $51.7 \%, 26.4 \%$, and $18.4 \%$ of the cases, respectively. Only 3 (3.5\%) patients had hemophilia B (two subjects with mild and one with severe bleeding disorders). The patients' ages ranged from 2 to 53 years (mean $\pm \mathrm{SD}=$ $15.8 \pm 11.3$ years). Of the 90 hemophiliacs, 55 were found to be seropositive by ELISA, and 54 were subsequently confirmed as being positive by LIA, resulting in an anti- 
HCV prevalence of 60\% (CI 95\%: 49.6-69.7). RNA-HCV was detected in 42 samples: 39 were anti-HCV positive, 2 were anti-HCV-negative, and 1 was indeterminate. These data resulted an overall $\mathrm{HCV}$ infection prevalence of $63.3 \%$ (CI95\%: 53.0-72.7).

Among all risk factors studied, age, number of previous blood transfusions, and dental treatment were significantly associated with $\mathrm{HCV}$ positivity by univariate analysis. However, multivariate analysis revealed that only number of blood transfusions was significantly associated with $\mathrm{HCV}$ infection in this population (Table). Almost all (97\%) hemophiliacs had received local, non-virus-inactivated blood products mainly cryoprecipitate. Also, of the 77 patients who were transfused before the introduction of anti-HCV screening of blood donors in Brazil, 57 (74\%) were infected by HCV. On the other hand, our results revealed that all hemophiliacs $(\mathrm{N}=13)$ who were transfused exclusively with products screened for anti-HCV were negative for RNA-HCV and anti-HCV.

The present investigation showed a high HCV infection prevalence in hemophiliacs in Goiânia city when compared to that found in local blood donors (1.4\%) (Martins et al. 1994). Nevertheless, with reference to other hemophiliacs populations, this rate was similar to that obtained in Minas Gerais, Brazil (62\%) and Canada (63\%) (Blanchette et al. 1994, Rocha et al. 1994), but lower than prevalences observed in the United Kingdom (76\%), the USA (89.3\%) and New Zeland (89.6\%) (Troisi et al. 1993, Jackson et al. 1994, Ahmed et al. 1996).

Dental treatment was a significant risk factor by univariate analysis. The potencial risk reported was previous dental procedure with a non-licenced dentist in a common dental office where many hemophiliacs were treated. Blood loss is frequent during treatment of these patients. In addition, probably sterilization procedures were not available in this dental office. Piazza et al. (1995)

TABLE

Risk factors associated with hepatitis $\mathrm{C}$ virus infection in hemophiliacs in Central Brazil

\begin{tabular}{lcc}
\hline Risk factor & $\begin{array}{c}\text { Crude OR } \\
(\text { CI 95\%) }\end{array}$ & $\begin{array}{c}\text { Adjusted OR } \\
(\text { CI 95\%) }\end{array}$ \\
\hline Age & 1.0 & 1.0 \\
$<10$ years & $6.6(1.8-25.1)$ & $3.6(1.0-12.9)^{a}$ \\
10- 20 years & $3.9(1.1-14.2)$ & $1.9(0.5-6.9)$ \\
$>$ 20 years & 1.0 & \\
Number of previous transfusions & 1.0 \\
$<50$ & $1.9(0.7-6.3)$ & $1.4(0.5-4.1)^{b}$ \\
$50-160$ & $21.0(3.7-155.9)$ & $10.7(2.0-57.5)$ \\
$>160$ & & \\
Dental treatment & 1.0 & 1.0 \\
No & $5.9(1.6-22.4)$ & $2.6(0.7-9.4)^{c}$ \\
Yes &
\end{tabular}

OR: odds rate; $\mathrm{CI}$ : confidence interval; $a$ : adjusted for number of previous transfusion and dental treatment; $b$ : adjusted for age and dental treatment; $c$ : adjusted for age and number of previous transfusion showed that contamination of dental surgeries, work benches, air turbine handpieces, holders, suction units, forceps, dental mirrors and burs by HCV could occur after tratment of $\mathrm{HCV}$-positive patients.

Regarding blood transfusions, multivariate analysis showed that patients who received more than 160 transfusions had a 10.7 -fold (95\% CI: 2.0-57.5) greater risk of $\mathrm{HCV}$ positivity compared to subjects who received less than 50 transfusions. Recentely, we found a similar HCV genotypes distribution between hemophiliacs and blood donors in Central Brazil (Martins et al. 2000).

Although this study showed a high HCV infection prevalence in hemophiliacs in Central Brazil, it also confirmed the expected decline in transfusion-acquired hepatitis $C$ in this population after the screening of blood units for anti-HCV became mandatory in Brazilian blood banks, a requirement which has contributed substantially to lower $\mathrm{HCV}$ infection prevalence in transfused patients.

\section{REFERENCES}

Ahmed MM, Mutimer DJ, Elias E, Linin J, Garrido M, Hubscher S, Jarvis L, Simmonds P, Wilde JT 1996. A combined management protocol for patients with coagulation disorders infected with hepatitis C virus. Br J Haematol 95: 383388.

Arteaga-Vizcaíno M, Blitz-Dorfman L, Echeverría JM, León P, Weir J, Diez-Ewald M, Vizcaíno G, Torres E, Porto-Espinoza L 1993. Hepatitis C in hemophilic patients from Maracaibo, Venezuela. Invest Clin 34: 113-118.

Blanchette V, Walker I, Gill P, Adams M, Roberts R, Inwood M 1994. Hepatitis C infection in patients with hemophilia: results of a national survey 1994. Transfus Med Rev 8: 210-217.

Ginabreda MGP, Yoshida CFT, Niel C 1997. Genomic characterization of Brazilian hepatitis $\mathrm{C}$ virus genotypes 1a and 1b. Braz J Med Biol Res 30: 339-345.

Jackson SR, Carter JM, Jackson TW, Green GJ, Hawkins TE, Romeril K 1994. Hepatitis C seroprevalence in bone marrow transplant recipients and haemophiliacs. $N \mathrm{Z} \mathrm{Med} \mathrm{J}$ 107: 10-11.

Martins RMB, Barbosa AP, Oliveira JM, Vanderborght B, Yoshida CFT 2000. Genotype analysis of hepatitis C virus in Brazilian hemophiliacs and blood donors. Vox Sang 78: 255.

Martins RMB, Vanderborght BOM, Rouzere CD, Santana CL, Santos CO, Mori DN, Ferreira RG, Yoshida CFT 1994. Anti- HCV related to HCV PCR and risk factors analysis in a blood donor population of Central Brazil. Rev Inst Med Trop S Paulo 36: 501-506.

Oliveira GC, Carmo RA, Rocha MOC, Silva MO, Lima AT, Guimarães MDC, Corrêa-Oliveira R 1999. Hepatitis C virus genotypes in hemophiliacs in the state of Minas Gerais, Brazil. Transfusion 39: 1194-1199.

Piazza M, Borgia G, Picciotto L, Nappa S, Cicciarello S, Orlando R 1995. Detection of hepatitis C virus-RNA by polymerase chain reaction in dental surgeries. $J$ Med Virol 45: 40-42.

Rocha VG, Carmo RA, Murao M 1994. Predictive factors for the presence of hepatitis $\mathrm{C}$ virus antibodies in hemophiliacs: multivariate analysis. Rev Soc Bras Med Trop 27: 368.

Troisi CL, Hollinger FB, Hoots WK, Contant C, Gill J, Ragni M, Parmley R, Sexauer C, Gomperts E, Buchanan G 1993. A multicenter study of viral hepatitis in a United States hemophilic population. Blood 81: 412-418. 